\title{
Analysis of bulk oil in Tulungagung district on physical and chemical properties
}

\author{
Taufik Salis Syaifudin $^{1 a}$, Rizqi Asri Fauzi Nugraha ${ }^{1 b}$, Indra Lasmana Tarigan ${ }^{1 c}$ \\ 1 STIKes Karya Putra Bangsa Tulungagung, Indonesia \\ a taufiksaliss@gmail.com \\ b nugraha.rizqi35@gmail.com \\ c indratarigan92@gmail.com * \\ * corresponding author
}

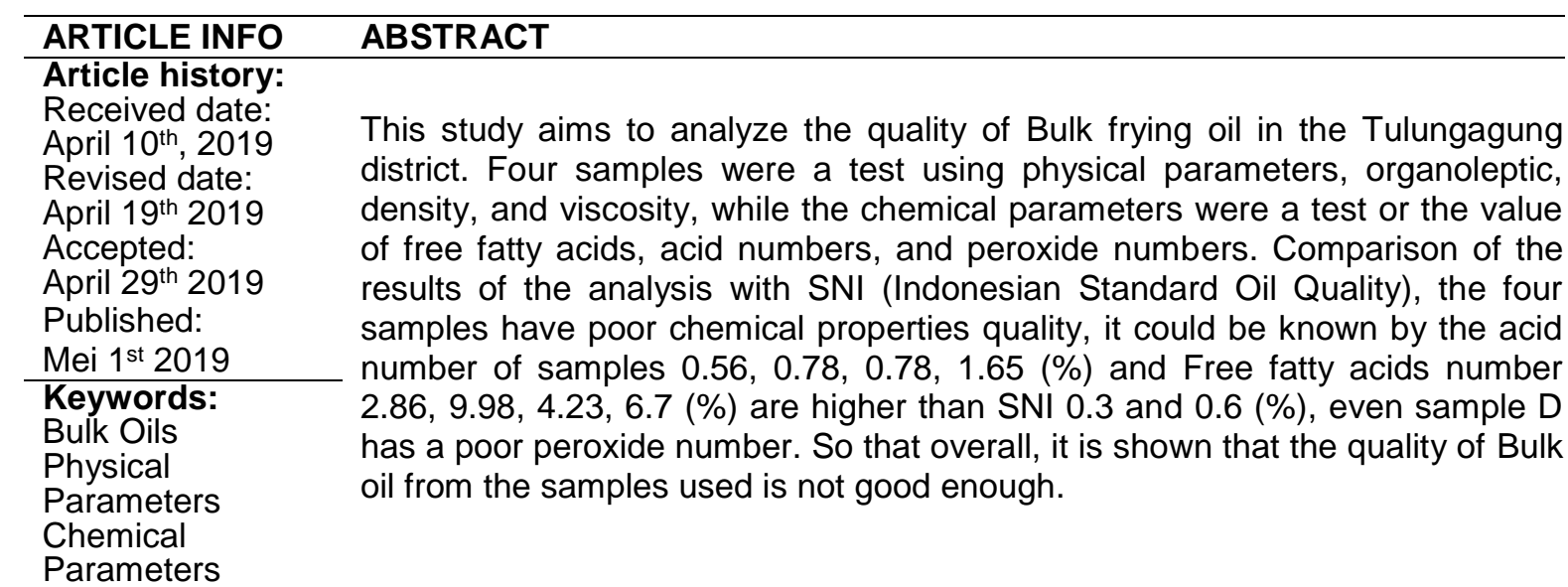

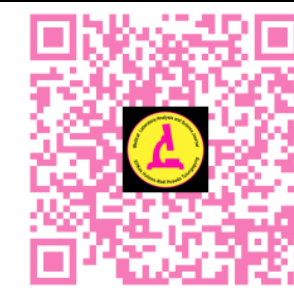

This is an open access article under the CC-BY-SA license

\section{INTRODUCTION}

Oil has a close relationship in human lives because almost in all foods have a different level of oil. Essential oils can be consumed, which are the source from either vegetable or animal ingredients. ${ }^{1}$ Vegetable oils are oils extracted from a plant, seed like corn oil, peanuts, soybeans, and palm oil, while animal oils are obtained from milk fat, beef fat and sardine oil.1.? In a different case of oil in meat, fish, milk, peanuts, and several other types of vegetables are usually consume with these ingredients known as hidden fat (invisible fat) whereas oil which is separated from its source and further, its purifies is known as visible fat. .3 Generally, oils are used as a delivery agent for heat (fried) known as cooking oils. 3,4 The oils have food ingredients with the main composition of triglycerides derived from vegetable ingredients with or without chemical changes including hydrogenation, cooling and has gone through the refining or purification process used for frying. ${ }^{4}$ There are various types of plants as a source of making cooking oil and one of them is from oil palm plants. Cooking oil is one of the basic needs of the community in meeting their daily needs. ${ }^{5,6}$ Cooking oil consumed daily is very closely related to health, and there are two types of cooking oil, namely Bulk cooking oil or unpackage cooking oil and package cooking oil. The difference of both lies in filtering which affects the quality of cooking oil. $\underline{7}$ 
Packaged cooking oil has twice filtered while Bulk cooking oil has one screening $\cdot \frac{8}{}$ Based on the research was conducted on the quality testing of Bulk cooking oil and packaging, the interrupted crackers frying for 10 hours resulted in an increase in free fatty acids $>0.5 \%$ which showed that the oil could no longer be used.. Another study of the quality of packaged cooking oil carried out during 10-hour frying of cooking oil resultant in an accumulation of free radical increase from existing free radicals and free radicals after heating. $\frac{10,11}{1}$ Based on the data, the amount of cooking oil needs reaches 3.2 metric tons per year and around $63 \%$ is sold as a Bulk cooking oil. Most consumers do not know and do not realize that poor quality of oil can cause various diseases such as, increase levels of Low-Density Lipoprotein (LDL) in the blood which can cause coronary heart disease, cardiovascular disease, hypertension and cancer. $\underline{12,13}$ Knowing the quality of cooking oil can be determined by analysis of water content, acid numbers, free fatty acid levels, and peroxide numbers. 11,14 Chemical oil quality analysis were carried out by testing peroxide numbers, acid numbers and free fatty acid levels. $\frac{15}{}$ In analysis of the quality of cooking oil can also be examined by determining the moisture content. Based on the background have been explained, the researcher conducts a study to determine the quality of Bulk cooking oil in the Traditional Market in Tulungagung Subdistrict conducted at the Chemical Laboratory of STIKes Karya Putra Bangsa Tulungagung.

\section{MATERIALS AND METHODS}

Our research type is a descriptive research, that describes the results of Bulk oil quality in Tulungagung District by using both physical and chemical properties analysis. Samples were taken by purposive sampling technique, which is provided in different store in Tulungagung district. The analysis technique is descriptive statistics that describe or give an overview of the object under study through sample or population data without analyzing and making conclusions that apply to the public. The sampling location taken from Tulungagung district areas and using five Bulk oil samples were used $A, B, C, D$, and $E$ which is getting from five different oil store. All sample was used not brand even without ingredient information. All processes of data testing and analysis were carried out in the Chemical Laboratory of STIKes Karya Putra Bangsa Tulungagung. We use several chemical materials, $\mathrm{KOH}$ (89\%, MERCK), $\mathrm{Na}_{2} \mathrm{~S}_{2} \mathrm{O}_{3}$ (98\%, MERCK), $\mathrm{HCl}(37 \%, \mathrm{MERCK})$, and Phenolphthalein indicator. Some instrument that we use, a set of titration equipment, pipet, Erlenmeyer, Viscometer and Pycnometer (Sigma-Adrich)

\section{Analysis of Physics Parameters:}

Measurements of physical parameters were carried out by organoleptically and density tests were compared with SNI. $\frac{16}{}$ Both samples were tested using a color route tool for organoleptic tests and density tests using weighing glass tools and analytic balance. Measurement and retrieval of data 3 times (triple) to avoid data errors and get consistent results. The color of palm cooking oil is determined by the presence of pigments that remain after the bleaching process because the fatty acids and glycerides are colorless. $\frac{11}{1}$ Orange or yellow due to the presence of carotene pigments which are soluble in oil. The smell and flavor in oil are naturally available, also due to the presence of short chain fatty acids due to oil damage. $\frac{17}{}$ While the typical smell of palm oil is caused by the beta-ionone compound. The melting point of palm oil is in the temperature range because palm oil contains several kinds of fatty acids which have different melting points. $\underline{18}$

\section{Analysis of Chemical Parameter:}

The measurement of chemical parameters was carried out using three tests, which are the free fatty acid test, peroxide number test, and sap test. Test free fatty acids by titration to determine the number of free fatty acids with the formula. Peroxide number test with titration technique using $0.1 \mathrm{~N} \mathrm{Na}_{2} \mathrm{~S}_{2} \mathrm{O}_{3}$. The saponification number test uses 2 stages 
which, $\mathrm{KOH}$ standardization with titration technique using $0.5 \mathrm{~N} \mathrm{HCl}$ and the second determines saponification number using a set of reflux and titrated using $0.1 \mathrm{~N} \mathrm{HCl} . \underline{19}$

\section{Free Fatty Acids:}

A total of $2 \mathrm{~g}$ of oil sample was weighed and put in Erlenmeyer. Then $50 \mathrm{~mL}$ of alcohol was added $95 \%$ neutral. 3-5 drops of fenoftalein indicator are added to the solution and titrated with a standard $0.1 \mathrm{~N} \mathrm{KOH}$. The end of the titration is achieved if a pink color is formed that does not disappear for 0.5 minutes. $\underline{20}$

$$
\begin{gathered}
\% \mathrm{FFA}=\frac{\mathrm{ml} \mathrm{KOH} \times \mathrm{N} \mathrm{KOH} \times \mathrm{MW} \text { Oils }}{\mathrm{m} \times 10} \\
\mathrm{~m}=\text { weight of oil (gr); MW: Moleculer Weight (gr) }
\end{gathered}
$$

Acid Number:

Oil is weighed as much as 10 grams. Added $50 \mathrm{~mL}$ of $95 \%$ neutral alcohol, then heated in a water bath for +10 minutes while stirring. The solution was titrated with $\mathrm{KOH} 0.05 \mathrm{~N}$ with 3-5 drops of fenoftalein indicator in alcohol, until it was exactly pink. $\underline{13,20}$

$$
\text { Acid Number }=\frac{A \times N \times 56,1}{\text { Weight sample }}
$$

$\mathrm{A}=$ The number of $\mathrm{ml}$ of $\mathrm{KOH}$ for titration; $\mathrm{N}=$ Normality of $\mathrm{KOH} ; 56,1=\mathrm{MW} \mathrm{KOH}$

Peroxide Number:

Cooking oil as much as $10 \mathrm{~g}$ is weighed and then put in a $250 \mathrm{~mL}$ closed Erlenmeyer flask. Subsequently, $12 \mathrm{~mL}$ chloroform and $18 \mathrm{~mL}$ glacial acidic acid were added to the flask. The solution is shaken out until all the ingredients are dissolved. After all the ingredients are mixed, $0.5 \mathrm{~mL}$ of saturated solution $\mathrm{KI}$ is added. For 1 minute the solution mixture was left to stand while still being shaken out, then added $30 \mathrm{~mL}$ of distilled water. Next, into the mixture, the $0.5 \mathrm{~mL} 1 \%$ starch is added and immediately titrated with $\mathrm{Na}_{2} \mathrm{~S}_{2} \mathrm{O}_{3} 0.1 \mathrm{~N}$ until the solution changes color from blue to blue and begins to disappear. Determination is done by repeating twice.

$$
\text { Peroxide Number }=\frac{\left(\mathrm{V}_{0}-\mathrm{V}_{1}\right) \times \mathrm{N} \mathrm{Na}_{2} \mathrm{~S}_{2} \mathrm{O}_{3} \times 1000}{\text { Weight sample }}
$$

$\mathrm{V}_{0}=$ volume titrasi $\mathrm{Na}_{2} \mathrm{~S}_{2} \mathrm{O}_{3}$ pada sampel; $\mathrm{V}_{1}=$ volume titrasi $\mathrm{Na}_{2} \mathrm{~S}_{2} \mathrm{O}_{3}$ pada blangko; $\mathrm{N}=$ Normalitas $\mathrm{Na}_{2} \mathrm{~S}_{2} \mathrm{O}_{3}$

\section{RESULTS AND DISCUSSION Physical Properties}

Analyzing and testing the physical properties of bulk oil, we approach by several indicators or parameters are used in, including organoleptic, oil density, and thickness. The organoleptic results showed that all bulk oil samples had uniform / same color ie light yellow (tend to be clear), and did not have a strange aroma (normal). $\underline{12}, \underline{21}$ The density indicator is measured using density pumpkin, and the measurement results are obtained as shown in table 1.

Density Point: To analyze the density of the oil sample, we used analytical scales and measuring cups are used by comparing mass with volume to get the comparison. Density point obtained by compared mass/volume, as showing in table 1. 
Table 1. The Results of Bulk Cooking Oil Density

\begin{tabular}{ccccc}
\hline No & Samples & Volume (ml) & Weight (gr) & Density \\
\hline 1 & A & 5 & 5 & $1 \mathrm{Kg} / \mathrm{m}^{3}$ \\
\hline 2 & $\mathrm{~B}$ & 5 & 5 & $1 \mathrm{Kg} / \mathrm{m}^{3}$ \\
\hline 3 & $\mathrm{C}$ & 5 & 4,7 & $0,94 \mathrm{Kg} / \mathrm{m}^{3}$ \\
\hline 4 & $\mathrm{D}$ & 5 & 4,6 & $0,92 \mathrm{Kg} / \mathrm{m}^{3}$ \\
\hline
\end{tabular}

The results of bulk oil bulk analysis, it was found that samples $A$ and $B$ had relatively the same density with water, while samples $C$ and $D$ had a density of standard 0.9 .

Viscosity Point: Viscosity is a measure that states the thickness of a liquid or fluid. Viscosity is the nature of fluids that are closely related to obstacles to flow. Generally, the measurement of fluid viscosity coefficients is based on the resistance of the movement of objects in the fluid. $\underline{14,21}$

Table 2. The Results of Bulk Cooking Oil Viscosity

\begin{tabular}{ccccc}
\hline No & Oil Sample & Density & Sample Time & Viscosity \\
\hline 1 & A & $1 \mathrm{Kg} / \mathrm{m}^{3}$ & $7 \mathrm{~s}$ & $14(\mathrm{~N} . \mathrm{s}) / \mathrm{m}^{2}$ \\
\hline 2 & $\mathrm{~B}$ & $1 \mathrm{Kg} / \mathrm{m}^{3}$ & $8,4 \mathrm{~s}$ & $16,8(\mathrm{~N} . \mathrm{s}) / \mathrm{m}^{2}$ \\
\hline 3 & $\mathrm{C}$ & $0,94 \mathrm{Kg} / \mathrm{m}^{3}$ & $10,12 \mathrm{~s}$ & $19(\mathrm{~N} . \mathrm{s}) / \mathrm{m}^{2}$ \\
\hline 4 & $\mathrm{D}$ & $0,92 \mathrm{Kg} / \mathrm{m}^{3}$ & $9,54 \mathrm{~s}$ & $17,5(\mathrm{~N} . \mathrm{s}) / \mathrm{m}^{2}$ \\
\hline
\end{tabular}

Our results of viscosity were shown in table 2 that indicates the thickness of oil $A$ has the smallest viscosity value and oil $C$ has the greatest viscosity. Good oil has a large viscosity, so it can be concluded that oil $C>D>B>A$ shows the order of quality.

\section{Chemical Properties}

Free Fatty Acids (FFA)

In this study, we was used acid-base titration method with a $0.1 \mathrm{~N}$ standard $\mathrm{KOH}$ solution for measuring free fatty acids. We added oil into alcohol, the purpose of adding alcohol into oil, that supposed oil can be dissolved and can react with alkaline bases so that it is easy to titrate. $\underline{21}, \underline{22}$ The increase in the number of free fatty acids can also be caused due to high water content so that it speeds up the hydrolysis of cooking oil. The presence of water in the oil will accelerate the hydrolysis process of cooking oil. $\underline{15}, \underline{21}$ The results of the analysis of free fatty acids from bulk cooking oil can be seen in table 3 .

Table 3. The Results of Bulk Oil Free Fat Acid

\begin{tabular}{ccccc}
\hline No & Oil Sample & KOH 0,1 N (ml) & \% FFA & Standard \\
\hline 1 & A & $1 \mathrm{ml}$ & $0,56 \%$ & $0,30 \%$ \\
\hline 2 & $\mathrm{~B}$ & $1,4 \mathrm{ml}$ & $0,78 \%$ & $0,30 \%$ \\
\hline 3 & $\mathrm{C}$ & $1,3 \mathrm{ml}$ & $0,78 \%$ & $0,30 \%$ \\
\hline 4 & $\mathrm{D}$ & $2,7 \mathrm{ml}$ & $1,65 \%$ & $0,30 \%$ \\
\hline
\end{tabular}

The results of measurement of free fatty acids in four bulk oil samples, it was found that all samples $A, B, C$, and D had relatively high FFA values, compared to SNI standards, this 
indicated that the four bulk oil samples had values below standard, and were not good for use. $. \underline{17}, \underline{22}$

\section{Acid Number}

Acid numbers indicate the amount of $\mathrm{mg} \mathrm{KOH}$ needed to neutralize $1 \mathrm{gram}$ of oil sample. The method used in this experiment is titration. The addition of alcohol aims to dissolve the oil so that it is easy to titrate. The measurement results can be seen in table 4.

Table 4. The Result of Bulk Oil Acid Number

\begin{tabular}{ccccc}
\hline No & Oil Samples & V. KOH 0,05 N & \% Acid Number & Standar \\
\hline 1 & A & $5,1 \mathrm{ml}$ & $2,86 \%$ & $0,60 \%$ \\
\hline 2 & $\mathrm{~B}$ & $17,8 \mathrm{ml}$ & $9,98 \%$ & $0,60 \%$ \\
\hline 3 & $\mathrm{C}$ & $7,1 \mathrm{ml}$ & $4,23 \%$ & $0,60 \%$ \\
\hline 4 & $\mathrm{D}$ & $11 \mathrm{ml}$ & $6,70 \%$ & $0,60 \%$ \\
\hline
\end{tabular}

Standard adopted SNI $2013(\leq 0.6 \mathrm{mg} \mathrm{KOH/g})$

The results of an Acid number of Bulks Oil was shown in Table 4, show that all samples have as much acid number as higher than the standard, SNI 01-3741-2002 which is $0.60 \%$ (b/b). $.18, \underline{20}$ So that all bulk oil samples used from the Tulungagung sub-district are not suitable for consumption from this parameter, because oil acid number related to free fatty acid that may induce human risk disease..$\underline{22}$

\section{Peroxide Numbers}

The peroxide number of oils are indicated the degree of oil damage due to oxidation reaction. .0 The high peroxide number shows that the oil has been damaged and it will soon experience rancidity and already experiencing oxidation and may affect any disease such as cancer or cardiovascular. $\underline{20}, 21$

Table 5. The Results of Bulk Oil Peroxide Number

\begin{tabular}{ccccc}
\hline No & Oil Samples & $\begin{array}{c}\mathbf{V} . \mathbf{N a}_{\mathbf{2}} \mathbf{S}_{\mathbf{2}} \mathbf{O}_{3} \\
\mathbf{0 , 1} \mathbf{~ N}\end{array}$ & $\begin{array}{c}\text { Peroxide } \\
\text { Number }\end{array}$ & Standard \\
\hline 1 & $\mathrm{~A}$ & $0,4 \mathrm{ml}$ & $8 \%$ & $<10 \%$ \\
\hline 2 & $\mathrm{~B}$ & $0,2 \mathrm{ml}$ & $4 \%$ & $<10 \%$ \\
\hline 3 & $\mathrm{C}$ & $0,3 \mathrm{ml}$ & $6 \%$ & $<10 \%$ \\
\hline 4 & $\mathrm{D}$ & $1,8 \mathrm{ml}$ & $36 \%$ & $<10 \%$ \\
\hline
\end{tabular}

Standard adopted SNI $2013\left(\leq 10\right.$ mek $\left.\mathrm{O}_{2} / \mathrm{kg}\right)$

To determinate the peroxide number of sample was carried out by the titration method, which is adding alcohol to the $\mathrm{KOH}$ standard to dissolve the oil as well, then titration by $\mathrm{Na}_{2} \mathrm{~S}_{2} \mathrm{O}_{3} 0.1 \mathrm{~N}$. $\underline{\text {.2 }}$ We have found that samples $\mathrm{A}, \mathrm{B}, \mathrm{C}$ have peroxide numbers which are below the maximum standard of SNI. But in sample $D$ it has a peroxide number greater than the standard SNI 1.8\%. This data has shown that sample D is not good enough to use.

Our data was support information related to physical and chemical properties of Bulk oil in Tulungagung district, almost $80 \%$ of all test indicators carried out did not find the standards of oil that were suitable for consumption life. This shows that the quality of Bulk oil have to improve so that it can achieve a standard worthy and proper to use consumption so that it will not affect human health. 


\section{CONCLUSION}

The analysis quality of sample oil shows that sample $A$ and $B$ have a density of 1 while oils $C$ and $D$ have densities ranging from 0.9 . Oil $C$ has the highest viscosity of 19 , while sample A has the lowest viscosity 14 . Moreover, the FFA value of the fourth samples is higher than the SNI standard $0.3 \%$, so that indicated samples are not well used. Moreover, the acid Number of all the sample oil also higher than the $0.6 \%$ standard (SNI), which is also complete our data that all of the sample are not good to use. Peroxide numbers of samples A, B, and C are smaller than SNI $10 \%$ while sample D is higher than SNI so that this indicator is not suitable for use.

\section{REFERENCES}

1. Winarno, F.G. (1997). Kimia Pangan dan Gizi. PT. Gramedia Pustaka Utama. Jakarta.

2. Silalahi, R.L.R., Sari, D.P., Dewi, I.A. (2017). Testing of Free Fatty Acid (FFA) and Colour for Controlling the Quality of Cooking Oil Produced by PT. XYZ, Jurnal Teknologi dan Manajemen Agroindustri, 6(1), 41-50. DOI: https://doi.org/10.21776/ub.industria.2017.006.01.6

3. Imoisi, O.B., Ilori G.E., Agho, I., \& Ekhator JO. (2015). Palm oil, its nutritional and health implication (Review). J. Appl. Sci. Environ. Manage, 19(1), 127-133. DOI: http://dx.doi.org/10.4314/jasem.v19i1.15

4. Putri,R., Budiyanto, B., \& Syafnil, S. (2016). Evaluate the Quality Changes of Frying oil during continuous frying of lemuru fish (Sardinella lemuru). Jurnal Agroindustri, 6(1), 1-7. DOI: http://doi.org/10.31186/j.agroind.6.1.1-7

5. Ilmi.I.M.B, Khomsan A, \& Marliyati.S.A. (2015). Kualitas Minyak Goreng dan Produk Gorengan Selama Penggorengan di Rumah Tangga Indonesia. Jurnal Aplikasi Teknologi Pangan. Jurnal Aplikasi Teknologi Pangan, 4(2), 61-65. DOI: http://doi.org/10.17728/jatp.2015.12

6. Pangestuti, D.R, \& Rohmawati, S. (2018). Peroxide Content in Cooking Oil Used By Fritter Traders in Tembalang Subdistrict Semarang City. Amerta Nutrition, Airlangga University, 2(2), 205-217. DOI: http://doi.org/10.2473/amnt.v2i2.2018.205-211

7. Nainggolan, B., Susanti, N., \& Juniar, A. (2016). Uji Kelayakan Minyak Goreng Curah dan Kemasan yang Digunakan Menggoreng Secara Berulang. Jurnal Pendidikan Kimia, 8(1), 45-57. DOI: http://doi.org/10.24114/JPKIM.V8I1.4424

8. Suandi, D.A.P., Suaniti, N., \& Putra, A. (2017). Analisis Bilangan Peroksida Minyak Sawit Hasil Gorengan Tempe Pada Berbagai Waktu Pemanasan dengan Titrasi Iodometri.Jurnal Kimia (Journal Of Chemistry), 11(1), 69-74. https://ojs.unud.ac.id/index.php/jchem/article/view/27548

9. Visioli, F., Franco, M., Toledo, E., Luchsinger, J., Willett, W.C., Hu, F.B., MartinezGonzalez, M.A. (2018). Olive oil and Prevention of chronic diseases: Summary of an International Conference. Nutrition, Metabolism and Cardiovascular Diseases, 28 (7), 649-656. DOI: https://doi.org/10.1016/j.numecd.2018.04.004

10. Taufik, M., \& Seftiono, H. (2018). Karakteristik Fisik dan Kimia Minyak Goreng Sawit Hasil Proses Penggorengan dengan Metode Deep-Fat Frying. Jurnal Teknologi Universitas Muhammadiyah Jakarta, 10(2), 123-130. DOI: https://dx.doi.org/10.24853/jurtek.10.2.123-130

11. Sopianti,D.S., Herlina, Saputra, H.T. (2017). Penetapan Kadar Asam Lemak Bebas Pada Minyak Goreng. Kementrian RISTEK Journal Katalisator Kopertis Wilayah X, 2 (2), 100-105. DOI: http://doi.org/10.22216/jk.v2i2.2408

12. Badan Standard Nasional Indonesia. SNI 7709. (2012). Syarat Mutu Minyak Goreng Kelapa Sawit. Dewan Standar Nasional: Jakarta

13. Kenechi, N. O., Felix, A., Linus, C., \& Kayode, A. (2017). Analysis on the Physicochemical Properties of Palm Oil Within Isialangwa Local Government Area of 
Abia State, Nigeria. International Journal of Bioorganic Chemistry, 2 (4), 159-162. DOI: http://doi.org/10.11648/j.ijbc.20170204.11

14. Siddique, B.M., Muhamad, I.I., Ahmad, A., Ayob, A., Ibrahim, M.A., Omar, M.AK. (2015). Effect of frying on the rheological and chemical properties of palm oil and its blends. J Food Sci Technol, 52(2), 1444-1542. DOI: http://doi.org/10.1007/s13197013-1124-6

15. Tarmizi, A.H.A., Ismail, R., \& Kuntom, A. (2016). Effect of Frying on the Palm Oil Quality Attributes - A Review. Journal of Oil Palm Research, 28(2), 143-153. DOI: http://doi/org/10.21894/jopr.2016.2802.01.

16. Nurminha, N. (2017). Pengaruh Penambahan Antioksidan Kunyit (Curcuma longa) Terhadap Bilangan Peroksida Pada Minyak Goreng Curah. Jurnal Analis Kesehatan Politeknik Kesehatan Tanjungkarang Indonesia, 4(1), 370-375. DOI: http://dx.doi.org/10.26630/jak.v4i1.422

17. Naseri.S, Mahmoudian.M.H, Yari.A.R, Molaghen.S., \& Mahmoodian.Z. (2018). Evaluation of Peroxide Value and Acid Number of Edible Oils Consumed in the Sandwich and Fast Food Shops of Qom, Iran in 2016. Archives of Hygiene Sciences, 7(2), 91-97. DOI: http://doi.org/10.29252/ArchHygSci.7.2.91

18. Maochong, L. (2014). Research on Edible Oil Quality and Safety System. International Conference on Mechatronics, Control and Electronic Engineering. 1(1), 732-736. DOI: https://doi.org/10.2991/mce-14.2014.158DO

19. Parkinson, L., \& Cicerale, S. (2016). The Health Benefiting Mechanisms of Virgin Olive Oil Phenolic Compounds. Molecules, 21(12),1-12. DOI: http://dx.doi.org/10.3390/molecules21121734

20. Babatunde, O.A., \& Bello, G.S. (2016). Comparative Assessment of Some Physicochemical Properties of Groundnut and Palm Oils Sold Within Kaduna Metropolis, Nigeria. IOSR Journal of Applied Chemistry (IOSR-JAC), 9(11), 26-30. DOI: http://doi.org/10.9790/5736-0911022630

21. Ebere, E. C., Amarachukwu, I. E., Wirnkor, V. A., \& Ngozi, E. P. (2017). Physicochemical Parameter of Palm Oil and Soil from Ihube Community, Okigwe, Imo State Nigeria. International Letters of Natural Sciences, 62(1), 35-43. DOI: http://doi.org/10.18052/www.scipress.com/ILNS.62.35

22. Yusibani, E., Hazmi, N.A., \& Yufita, E. (2017). Pengukuran Viskositas Beberapa Produk Minyak Goreng Kelapa Sawit Setelah Pemanasan. Jurnal Teknologi dan Industri Pertanian Indonesia, 9(1), 28-32. DOI: https://doi.org/10.17969/itipi.v9i1.6108 